\title{
One Hundred Years of Organized Labor in Illinois, 1881-1981
}

\section{J. Carroll Moody \\ Northern Illinois University

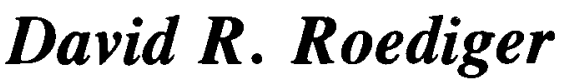

Northwestern University

The Illinois Labor History Society sponsored a conference, "One Hundred Years of Organized Labor in Illinois, 1881-1981,"' in Chicago on October 9-10. The conference attracted approximately one hundred academic historians and graduate students, trade unionists, and labor history "buffs" to the campus of the Illinois Institute of Technology, where the sessions were held. Also featured was a dinner honoring retired Chicago labor leaders Mollie Levitas and Joseph Keenan.

The Friday sessions were devoted to the presentation of ten papers which dealt with diverse topics and time periods. Richard Schneirov and Thomas Suhrbur, graduate students at Northern Illinois University, who are engaged jointly in writing a history of carpenters' unionism in Chicago under a grant from the Illinois Humanities Council, discussed a portion of their research, "Origins of the Brotherhood of Carpenters, 1866-1891." In tracing the organizational development of the union, the authors concluded that both the experience in the Knights of Labor and the militancy and class unity of German carpenters were major causes of the successes in building the Brotherhood. Stephen Freedman, a doctoral candidate at the University of Chicago, argued that the sources of union successes in Joliet-in the 1880 s and again during the 1919 steel strike-stemmed from inter-skills and inter-union solidarity. The community and organizational activities of nineteenth century Illinois coal miners were discussed by Richard P. Joyce in a paper titled "Early Struggles in the Mines of Northern Illinois, 1868-1900." Joyce's work expands upon Herbert Gutman's early work on Braidwood and addresses the relationships between miners, ethnicity and local politics. Gregory LeRoy, who has been engaged in research on a history of the Pullman porters under an NEH Youth-grant, discussed the effect of company unionism and paternalism, government investigations and rival union efforts between 1914 and 1924 as the backdrop for the organization of the Brotherhood of Sleeping Car Porters.

The afternoon session heard a discussion by Stephanie Booth of Gerry 
Allard, one of the famous of the Progressive Mine Workers of America. Booth's biography sparked expansive commentary on reform unionism in Illinois mines by Professor Milton Derber. Lester Brune of Bradley University traced the course of the 1936 strike of workers employed by the American Distillery Company in Pekin, which led to a three-day general strike in that city. Brune emphasized the ways in which the national press misperceived local realities. John Sillito, archivist at Weber State College in Idaho, discussed the activities of John Fitzpatrick and other Chicago labor leaders in the formation of the Farmer-Labor Party in 1920, and analyzed the causes for its short life. Eugene Miller and Gianna Panovsky presented plans for an ambitious study of radical Italians in garment worker organizations in Chicago from 1910 to 1930. Their research suggests the presence of a militant class-conscious leadership with continuing ties to ideological and political movements in Italy. Edward R. Gale, a doctoral candidate at the University of Minnesota, examined the interaction of union, employer, and city government in the Chicago taxicab industry from 1937 to the present. James Barrett of North Carolina State University, whose paper was presented by Robert Slayton, analyzed working-class diversity in the Chicago stockyards and the ways in which those workers employed strategies to overcome racial, ethnic, and skill differences to build successful unions during the first two decades of the twentieth century.

Saturday's session featured three panels of veterans of labor and union struggles. The first dealt with "Breaking In: the Black and Brown Experience," and featured Charles Hayes, International Vice-President of the Food and Commercial Workers; LeRoy J. Shackelford, Vice-President of the Allied Service Division of BRAC; and Jose Rio, President of Local 648 of the American Federation of Government Employees. The panelists recounted their experiences in getting their first jobs and how they became involved in the union movement. The second panel, "A Woman's Place in Shop and Union," included Mary Herrick, a pioneer Chicago teacher unionist in the 1920s, and Twyla Hayes, a journeyman carpenter. The third panel was titled, "Organize the Unorganized," and included Albert Verri and Robert Hatch who discussed their past and continuing experiences in organizing activities. The final day concluded with a summary panel of the committee which reviewed the paper proposals: Milton Derber of the University of Illinois, Albert Blum of IIT, and J. Carroll Moody of Northern Illinois University, wonderfully augmented by Ralph Helstein, President Emeritus of the United Packing House Workers, Amalgamated Meat Cutters.

Other activities at the Conference included a dinner on Friday night, which honored two veteran Chicago labor figures by inducting them into the ILHS "Union Hall of Honor": Sybil Mollie Levitas, secretary in the 1920s to John Fitzpatrick and Ed Nockels of the Chicago Federation of Labor, and Joseph D. Keenan, former International Secretary-Treasurer of the IBEW. On Saturday morning, the ILHS held its annual business meeting. The University of Illinois Press has expressed interest in publishing the papers presented at the conference, but in the meantime, ILHS can supply individual copies at five dollars each (20 E. Jackson Blvd., Chicago 60604). 